\title{
A network-based approach to dissect the cilia/centrosome complex interactome
}

\author{
M Morleo $^{1 *}$, R Amato ${ }^{1}$, L Giaquinto ${ }^{1}$, D Di Bernardo ${ }^{1,2,3}$, B Franco $^{1,2}$ \\ From Cilia 2014 - Second International Conference \\ Paris, France. 18-21 November 2014
}

\section{Objective}

We built a network of curated interactions between human proteins involved with centrioles, centrosomes, basal bodies and cilia to provide a global functional characterization of the Cilia/Centrosome Complex interactome (CCCI).

\section{Methods}

Human ciliary genes were collected from available databases and interactions among genes were obtained from the STRING database (http://string-db.org). Network analyses were performed using Cytoscape and communities were extracted using the MCODE algorithm. The genewise network was explored by Gene Ontology (GO) analysis. The transcription factor (TF) analysis was performed using information obtained from "ConsSites" and "tfbsConsFactors" track of the UCSC Genome Browser.

\section{Conclusions}

CCCI is a publically available tool, which will allow to clarify the roles of previously unknown ciliary functions and to elucidate the molecular mechanisms underlying ciliary-associated phenotypes.

\section{Authors' details}

${ }^{1}$ TIGEM, Pozzuoli, Italy. ${ }^{2}$ Department of Medical Translational Sciences University of Naples "Federico II", Naples, Italy. "'Department of Computer and Systems Engineering, University of Naples "Federico II", Naples, Italy.

Published: 13 July 2015

\section{doi:10.1186/2046-2530-4-S1-P87}

Cite this article as: Morleo et al:: A network-based approach to dissect the cilia/centrosome complex interactome. Cilia 2015 4(Suppl 1):P87.

\section{Results}

We collected 3,502 ciliary genes and obtained the final CCCI, which consisted of 11,608 interactions among 1,695 selected genes. We identified 90 communities, groups of genes densely interconnected with each other and connected to few genes outside the group. We discovered communities specialized for delegating specific biological functions such as mRNA processing, protein translation, folding and degradation processes. In particular the "proteasome community" was enriched in ciliary components belonging to the SYSCILIA Gold Standard (SCGSv1) and in ciliopathy genes. We found 11 communities enriched in 30 TFs. The identified TFs are involved in developmental processes, cell cycle control, in the immune response and in muscle differentiation.

${ }^{1}$ TIGEM, Pozzuoli, Italy

Full list of author information is available at the end of the article

Submit your next manuscript to BioMed Central and take full advantage of:

- Convenient online submission

- Thorough peer review

- No space constraints or color figure charges

- Immediate publication on acceptance

- Inclusion in PubMed, CAS, Scopus and Google Scholar

- Research which is freely available for redistribution 